\title{
Adopting Social Networking Sites (SNSs) as Interactive Communities among English Foreign Language (EFL) Learners in Writing: Opportunities and Challenges
}

\author{
Norizan Abdul Razak ${ }^{1}$, Murad Saeed ${ }^{1} \&$ Zulkifli Ahmad ${ }^{1}$ \\ ${ }^{1}$ Faculty of Social Sciences and Humanities, Universiti Kebangsaan Malaysia, Bangi, Selangor, Malaysia \\ Correspondence: Murad Saeed, Faculty of Social Sciences and Humanities, Universiti Kebangsaan Malaysia. Tel: \\ 60-111-551-8654.E-mail: muradsaeed16@yahoo.com
}

Received: June 6, 2013 Accepted: July 9, 2013 Online Published: October 10, 2013

doi:10.5539/elt.v6n11p187 URL: http://dx.doi.org/10.5539/elt.v6n11p187

\begin{abstract}
As most traditional classroom environments in English as Foreign Language (EFL) still restrict learners' collaboration and interaction in college writing classes, today, the majority of EFL learners are accessing Social Networking Sites (SNSs) as online communities of practice (CoPs) for adopting informal collaborative learning as a way of practicing English beyond the classroom. This study aimed to investigate the opportunities and challenges of SNSs as learning environment in writing in English. The study was conducted among 24 active and regular EFL learners joining the Only for English Learning Facebook (FB) CoP - a group developed and maintained by a few instructors in English - for EFL learners coming from different EFL Arab countries. The data was collected from the learners' interactional exchanges in the weekly posted writing activities as well as their responses to online open questions posted by the instructor. Based on the mixed analysis of the data, the quantity of the EFL learners' participation in the writing activities highly increased in the second session. Moreover, the learners were motivated to generate ideas, write their paragraphs and scaffold each other in paragraph writing. The findings also revealed that the EFL participants perceived this CoP as an interactive learning environment that contributed to enhancing their writing by engaging in learner-learner and learner-instructor interaction, information sharing, communicating and socializing with friends and developing a sense of belonging. However, a few challenges faced by the participants in such an online CoP were identified by the participants, and therefore, some valuable assistive features are suggested to be involved in the FB CoP for achieving further EFL development in the future.
\end{abstract}

Keywords: Social Networking Sites (SNSs), Communities of Practice (CoPs), facebook group, EFL writing

\section{Introduction}

\subsection{Introduce the Problem}

Research on second language (L2) acquisition or language learning based on the Interactionist framework that is originated from the sociocultural framework (Vygotsky 1978) emphasized the importance of collaborative learning and learner-learner meaningful interaction. From the perspective of this Interactionist framework, Chapelle (2003, p.56) explains that "interaction between people is expected to promote negotiation of meaning, and if it does so, this should be beneficial for language acquisition". Yet, the majority of English as a foreign language (EFL) classrooms tend to lack the necessary characteristics of interactive learning environment where learners can be engaged in active participation and dynamic interaction to use and practice English for various authentic purposes (Murad \& Norizan, 2012). This learning environmentrestricts EFL teaching and learning to delivering and receiving information with no or less opportunities for their students to interact and collaborate actively in classroom activities (Cloete et al., 2009).

However, today, due to the rapid advances of Social Network Sites (SNSs) as collaborative technologies, the opportunities for EFL learners to access such online interactive environments are increasing. As a fashionable way of learning and practicing English, EFL learners can collaborate and interact via SNSs outside the traditional classroom. This recent increasing application of SNSs as online Communities of Practice (CoPs) has not only been exclusive to personal, social and cultural identities and relationships, but it has also been ushered in education for the last few decades. As stated by Beer and Burrows (2007); Cloete, de Villiers, and Roodt 
(2009); Boyd and Ellison (2011); Lim (2012), SNSs have offered the opportunity for such self-direction with their ability to re-structure hierarchies, inform and reconfigure communication, and transform relationships with knowledge and people. Having their unique features and capabilities of re-organizing the way knowledge is acquired and used among people, Lave and Wenger (1991) pointed out that "these technologies are dramatically transforming the basic patterns of communication and knowledge interchange in society" and are re-defining "what it means to know, understand, and become a 'literate' or an 'educated citizen"” (p.12). One of the main educational benefits of using SNSs is that they provide learners with more chances for interaction to face the common dilemma of negotiating their studies. Another benefit of using SNSs is that they allow learners to enter new active learning environments of collaborative and interactive learning, often based on their interests and affinities not catered for in their immediate educational environment. Facebook (FB), as one of these SNSs, is another informal system equipped with tools designed for social interaction that students are re-appropriating for learning purposes (Lampe, Wohn, Vitak, Ellison, \&Wash, 2011). Therefore, collaborative technologies play a key role in shaping community environment and interaction, as they compensate for the lack of physical space.

Yet, the application of SNSs is still a novelty as it has been practiced by a small minority of instructors especially in the EFL context. Moreover, according to Beer and Burrows (2007), despite the evidence of the potential of SNSs in assisting learners to share, exchange and construct knowledge and form various modes of communication, interaction and collaboration, the exciting potential of such new technologies especially in ESL/ EFL contexts is yet to be fully explored. Therefore, the present research aimed to investigate the opportunities and challenges faced by the EFL in writing in the only for English Learning Facebook Cop.

\section{Literature Review}

\subsection{Theoretical Framework}

Interaction is a mutual activity which requires at least the involvement of two persons and which causes mutual effect. Ellis $(1999$, p.1) defines interaction as "the social behavior that occurs when one person communicates with another". He also says that it "can occur inside our minds, both when we engage in the kind of "private speech' discussed by Vygotsky (1978), and, more covertly, when different modules of the mind interact to construct an understanding of or a response to some phenomenon". According to Long's (1996) Interactionist Theory, interaction is an interactive means of language learning. In his latest version, Long (1996) claimed that interactive learning tasks that promote meaning negotiation among learners can facilitate their language development. Meaningful negotiation is seen as a result or product of learners' interactional exchanges where communication breakdowns exist. Moreover, Swain (1985) calls this kind of collaborative learning as "collaborative dialogue" for interlanguage development. Long (1996) adds that such meaningful interaction and negotiation provide learners with two kinds of linguistic evidence namely; positive evidence and negative evidence. The former refers to the state in which an interlocutor corrects a linguistic utterance by providing the correct form. The latter means that the learner receives feedback on their incorrect output. Such types of evidence promote learners' modified output. In other words, as stated by Swain (1985), learners are pushed to re-phrase and correct their output. Without this pushed output, they might engage in input comprehension (process meaning) rather than linguistic forms. Thus, in brief, this framework assumes that as learners interact with one another, they scaffold each other in the language and those being scaffolded or assisted by their peers are pushed to produce interactionally modified output (Swain 1985).

Wenger (1998) defines a CoP as a group of learners or practitioners being involved in an active learning environment with particular and obvious goals and purposes through social interaction. According to Lave and Wenger (1991), CoPs are also defined as 'a set of relations among persons, activity, and world, over time and in relation with other tangential and overlapping communities of practice' (p.98). The theory of CoP basically stresses that "learning as a social participation' (Wenger 1998, p.4) which refers to 'an encompassing process of being active participants in the practices of social communities and constructing identities in relation to these communities' (Wenger 1998, p.4). Learning is a process by which newcomers become included in a CoP where they develop skills and knowledge (including language) through active participation in a given communities' activities and by interacting with more experienced community members (Lave \& Wenger, 1991). Thus, Wenger (1998) stated "learning is 'a process of becoming, to be a certain person and it is also part of our participation in our communities and organizations' (p.8). According to Plastina (2009), this theory emphasizes the existence of full participants as an essential key element in successful CoPs, which denotes the individual social relations as an empowering process that enables newcomers to progress by pushing them to move from the periphery of the community towards its centre. Therefore, learners of a given CoP need to be encouraged as to develop a sense of belonging to that particular community. 


\subsection{Benefits of Online Interaction and Communication}

Underlying this Interactionist framework, there has been a wide number of previous studies which view learning as an interactive social act. With the emergence of Computer Assisted Language Learning (CALL), many studies have investigated learners' synchronous interaction via technologies from this theoretical perspective. Most of these studies highlighted the benefits of learner-learner synchronous interactional exchanges in reading and writing (Tannacito 1999); communication skills (Kitade 2000); quantity and quality of learners' production or output (Kern 1995 \& Kitade 2000); amount of participation (Chapelle 1994); motivation (Kern 1995). Some of these studies also emphasized how such learner-learner synchronous interaction assisted learners to attend to accurate linguistic forms, negotiated meaning and promoted lexical aspects of the language. However, most of these previous studies have not focused on the learner-learner synchronous interactional exchanges in pre-writing or writing tasks. Moreover, their focus was on interaction among learners as taking place in synchronous mediated communication (SMC) tools (e.g. interaction in chat rooms) while they neglected interaction in synchronous mediated communication and especially in social networks as in Facebook groups or pages. Regarding the role of Facebook in the writing process, only a few studies conducted by Haverback (2009); Shih (2011); Majid et al., (2012) have revealed that Facebook facilitates learners' writing process since it provides them with a learning environment in which they can interact, share, discuss and scaffold one another in their writing. Yet, these studies have not reflected on learner-learner interactional exchanges in writing and provided results based on statistic analysis of the participants' scores in writing and perception of learning through surveys.

\subsection{Benefits and Challenges of Facebook for ESL/EFL Learners}

The role of Facebook as one of the most popular SNSs among many Englisd as a second language (ESL) and EFL learners at university levels in providing them with opportunities to create and join groups within this online community has been recently invistigated by Boyd and Ellison (2011); Kamarul Kabilan, Norlida Ahmad, and Zainol Abidin (2010); Yunus, Salehi, and Chenzi (2012). It also assists learners joining such groups or communities to obtain, construct and exchange information and knowledge (Selwyn, 2007). In such communities, it is up to the individual user (or groups of users) to decide and choose what to discuss and who they want to work together with. According to Lampe et al., (2007), SNSs like Facebook can function as a surveillance for a CoP since it provides learners with the opportunity to "track the actions, beliefs and interests of the larger groups to which they belong" (p.167). Moreover, Facebook groups have been proved to assist ESL learners in their writing process (Haverback, 2009; Shih, 2011; Majid, Stapa, and Keong, 2012).

Reflecting on previous research conducted in writing or writing process in ESL and EFL contexts, most of these studies have applied other SNSs and Web 0.2 technologies including blogs, wiki, etc. Only a very limited number of studies have used Facebook for writing. However, the current study is proposed to investigate the collaborative writing process in this Facebook CoP for EFL learners for several reasons. First, currently, Facebook is regarded as the most well-known social network among university students especially EFL students (Majid et al., 2012). Secondly, Facebook has become a valuable social network that facilitates learners' communication and collaboration since it has the features of wall", "info", "blog", "friends", "like", "unlike", "comment", "poke", "send message", "share photos", "links", and "video" which provide learners with various opportunities to communicate, interact and collaborate with people around (Liu, 2010; Shih, 2011). Thirdly, empirical findings of a few recent studies have revealed the effectiveness of Facebook in facilitating ESL/EFL learners' active participation and engagement (Haverback, 2009) and out of classroom communication, collaboration and work (Roblyer, McDaniel, Webb, Herman \& Witty, 2010).

Although the potential of SNSs in general and Facebook in particular in providing language learners with the opportunities to be involved in online learning communities to practice English and writing skill is evident, several previous researchers have identified several challenges faced by learners in using Facebook as part of classroom learning. These challenges include learners' privacy (Rosenblum, 2007), tricky relationship between students and teachers (Simon, 2008), learners' diminished completion rates and inability to control their learning (Grandzol \& Grandzol, 2010) and learners' waste of time, development of negative habits and attitudes and arrangement of time (Kamarul Kabilan et al., 2010). Moreover, other challenges identified by Yunus et al., (2012) are learners' distraction, using short forms and abbreviations that might affect their writing and uncertainty of the accurate online information. 


\section{Study}

\subsection{Research Questions}

The current study aimed to provide answers to these three research questions:

Q1. Does the Facebook group as an online learning community foster the EFL learners' colloberation and interaction in paragraph writing activities?

Q2. How does the Facebook group as an online learning community facilitate the EFL learners' colloberation and interaction in paragraph writing activities?

Q3. How do the EFL learners describe their learning experience in writing activities in this CoP via facebook?

\subsection{Research Design}

The current study adopted a mixed action research approach to data collection as to answer the research questions, thus, achieving the major aim of the study. This type of research was selected because it involves planning the action needed to be carried out and then, this is followed by one's or practitioner's reflection on how the action or practice has been working" (McNiff and Whitehead, 2006).

\subsection{Research Context}

The Only for English Learning FB CoP was launched in June 2011 by the researchers specifically for the purpose of providing EFL students with a space where they can use and practice English for real communication and where they can create, share, exchange content and information and express themselves outside the traditional classroom settings. The group has attracted many EFL learners coming from different countries through the useful posts varying from video, written texts, pictures, etc in listening, reading, grammar, vocabulary and writing provided by the instructors. The number of the members reached 5,213 members by 4 May 2012. However, for the current study, it was only based on the data collected from 24 EFL learners coming from different Arab countries (14 females and 10 males). A purposive sampling aiming to seek certain criteria or characteristics in the samples which can be pre-informed by certain theories (Bogdan and Biklen, 2007) was adopted in this study. The first criterion is the variation among learners in terms of their levels in English. This is because the study is based on the notion of scaffolding and assistance provided by more capable learners to those less capable peers. This was evident by the findings of several empirical studies on ESL collaborative writing (Maftoon \& Ghafoori, 2009; Brooks, 2010; Yu \& Choe, 2011) among heterogeneous groups.

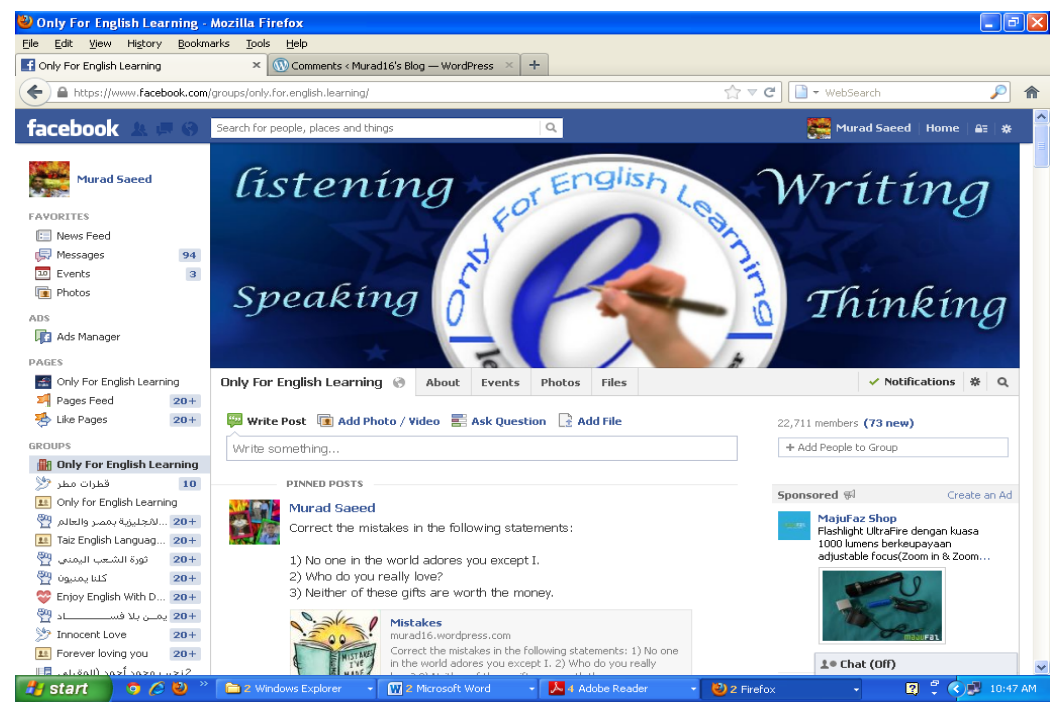

Figure 1. The only for English learning facebook group

\subsection{Research Procedure}

Besides The Only For English Learning Facebook CoP, the instructors created a blog (Figure 1) and connected it to the group so that any new post (activity or exercise) is posted in the blog can be published in the Facebook $\mathrm{CoP}$ as a way to help the learners to avoid being distracted by other many posts posted on daily basis. This can be also utilized for the writing process activities as to make them easily tracked by the respondents since they are distinguished from other activities or posts in the same CoP. Thus, in conducting the action project, the 
instructors and researchers introduced the writing activities to the EFL learners who were members of the Only For English Learning Facebook CoP. These activities were announced on 10 Janurary 2012 and secduled twice a week and continued till 19 July 2012, a period during which the participants practiced pre-writing, writing and post-writing. The focus was on paragraph writing and the instructors acted as facilitators for the group members in order to ensure that the EFL participants were feeling the presence of the instructors who facilitated and provided their last comments on the learners' writing activities.

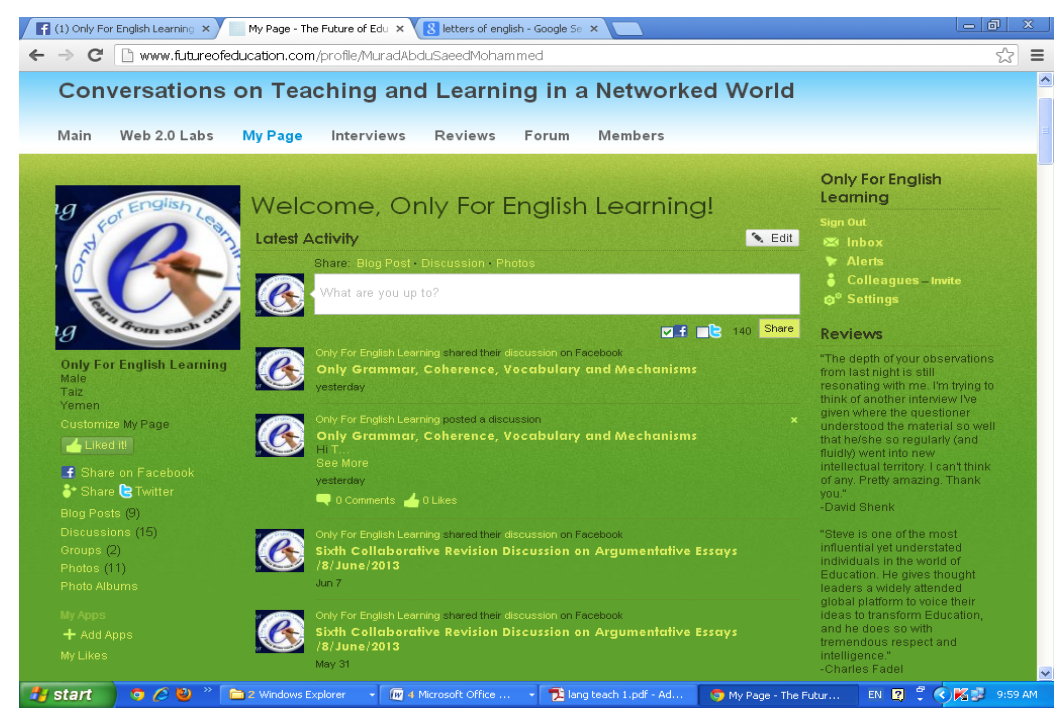

Figure 2. Forum print screen

For the data collection procedure, the instructors' online writing posts and participants' online interaction exchanges were collected and saved by the researchers after each activity ended. The EFL learners' original pargraphs and revised pargraphs during the projects were also collected as another source of data. They served as a source of data for a quantitative analysis. Subsequent to the collection of these writing paragraphs and commentary exchanges, the instructors conducted two online group discussions and the participants were invited to answer and discuss several open ended questions. These questions aimed to obtain the learners' views of the opportunities and challenges in writing in this CoP.

In analyzing the data, a mixed approach was utilized in this study. First, the EFL participants' interactional exchanges in the writing activities were statically counted using frequencies of occurrence as to answer the first research question regarding the learners' quantitity of participation. Moreover, the researchers reflected on these interactional exchanges for the qualitative analysis of the second research question. In other words, the focus of this reflection was on the learners' interactive dialogue, peer scfolding and negotitation in these writing activities and samples of their interaction were selected to represent the findings. For the learners' original and revised paragraphs in each activity, they were compared and the changes made by the learners as a way of incopoerating their peers' corrective feedback in their revised pargraphs were statically counted as to support the qualitative analysis of the finding. Finally, the EFL learners' responses to the online reflection discussions were subjected to a qualitative analysis to answer the third research question. According to Schilling (2006), this type of qualitative analysis suits this data and it aims to reveal or model people's information related behaviors and thoughts. The analysis was proceeded in the following steps adopted from Weber (1990) and Schilling (2006) preparing the data, defining the participants' answers and comments as the unit of the analysis, developing categories and coding schemes and reporting the findings by using quotes from the participants' opinions.

\section{Results and Discussion}

The quantative analysis of the EFL learners' posted exchanges and comments in the writing activities revealed that these writing activities as part of shared practive in this online community fostered the learners' participation and engagement. It was found that the number of the EFL participants' comments and exchanges was only 251 in the first session of writing activities whereas it reached 525 in the second session. This difference in the number of their exchanges and comments in the two sessions (274) reflects the EFL learners' increase in their participation. This could be an indication of their increasing interest and motivation in these writing activities. This result also indicates that there were some participants who were still peripheral in this community in the 
first session since they just joined the community several days before participating in the activities. However, within time, they became more familiar and started to move twards the active position of participation and membership. Another reason could be the motivation and ecouragment provided by the instructor to the learners during the sessions. This is what was pointed out by Wenger (1998). According to this theory of CoP, members of a given CoP assume a peripheral level of membership, and within time, they build relationship with others, get motivated and pushed twards the active level of membership (Plastina 2009).

The findings of the present study indicated that the EFL learners' engagement and interaction with the members of the $\mathrm{CoP}$ through posts and comments assisted them to enhance their writing in English. The potential of FB groups in enhancing students' writing in various contexts has been believed by researchers as such online FB communities can empower students with opportunity to link what is taught at college to use it in an authentic and personalized context, thus, aiding their writing skill in English (Roberts, 2009; White, 2009; Lim, 2012). The participants were assigned by the instructors to write paragraphs on different topics relevant to their own past experience, situations or description of other personalities. Therefore, such online writing activities provided them with opportunities to express their ideas, feelings and opinions. As shown in Excerpt (1) extracted from one of the weekly pre-writing activities posted by the instructor in the CoP, the students were involved in generating ideas and posting them in the form of initial drafts of paragraphs in various topics in free writing.

Instructor: Invitation (3) to start with this prompt (I need to remember.......), write for 10 minutes about forgiveness in your own simple words, and then post ur sentences here please. Can you?

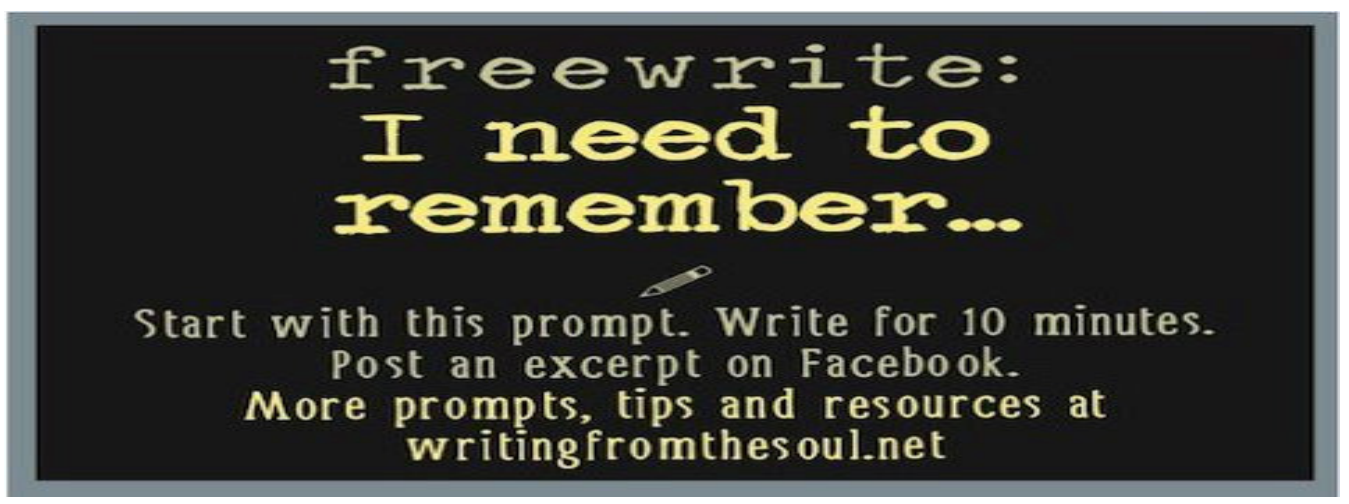

Samir Alqubati: I need to remember always that this life is not everlasting. One day we will die and leave everything behind. This gives me a good relief from the daily shocks of this life. When keeping this in mind, I feel more comfortable and relieved. I also need to remember that this life will be so boring if it is only white colour. Black and white keeps things more charming and beautiful. Life will have no meaning without suffering, pain and difficulties. There should be a balance in everything and that will no more affect my mode and will always lead to comfortable life.

Zaina Natour: I need to remember that life is too short. So, we shouldn't have hard feelings, over worry about our future or be angry all the time. We should seize the moment, live our life, enjoy it and keep smiling. We might face tough times and many difficulties during, but we can beat them by the help of; our friends, our families and our optimism. I also need to remember my dad's smile as it always helps me to feel better. The one thing I strongly need to remember is to be myself not anyone else. To live my life as I wish, not like others think I should! Finally, I need to remember that i have been blessed by Allah to have such great people in my life, what made me stronger and also much happier.

The findings confirm previous findings obtained by Sun and Chang (2012) as the researchers found that the mixed-method analysis of seven EFL graduate students' collaborative dialogues via web technologies like blogs provided them with opportunities to provide corrective feedback and scaffolds, thus, enhancing their writing tasks and processing academic writing knowledge. Similarly, in examining the effectiveness of FB group in ESL learners' writing skill development, Yunus et al., (2012) carried out a study among Malaysian ESL third year students doing their bachelor's degree in Teaching of English as a Second Language (TESL) at Universiti Kebangsaan Malaysia (UKM). Findings generated from their perception of FB group revealed that the group engaged the participants in writing process particularly in the brainstorming process before the actual writing. They could reduce their spelling errors, come up with better ideas based on their peers' posted ideas, and complete their essay writing successfully. In contrast to the findings of the current study, the findings gained by Rubesch \& McNeil (2010) displayed that some online ESL students expressed their frustration of online interactive activities such as peer reviewing activities were frustrating when they had to wait for classmates' 
feedback.

The online sample post-writing paragraph activities showed that the EFL learners collaborated and provided scaffolds to each other in revising their original paragraphs as well as revised paragraphs. Following pre-writing activities, the instructor requested the participants to provide corrective feedback and scaffolds on one another's paragraph (Excerpt 2).

Instructor: Please Tunisiano Ib, Zaina Natour etc ur comments on each other here are needed so can u?

Zaina Natour: hey Samir Alqubati: A few modifications of your writing in brackets

"I need to remember always that this life is not everlasting. One day, we will die and leave everything behind. This gives me a good relief from the daily shocks of this life. When keeping this in mind, I feel more comfortable and relieved. I also need to remember that this life would be so boring if it is only white colour. (I also need to remember that it would be so boring if this life was only white). Black and white keeps things more charming and beautiful. Life would have no meaning (would be meaningless) without suffering, pain and difficulties. There should be a balance in everything and that will no more affect my mode and will always lead to comfortable life. (Everything should be balanced, thus it wouldn't affect my mood anymore and would lead me to a more comfortable life ".

As shown in Excerpt (3), the learners were involved in negotiating the accuracy of the linguistic form of the verb used in Zaina's revision of one paragraph. The sentence in the original paragraph written by one of them (Nowadays, I am forgetting all the grammar rules I have learnt.) was re-phrased by Zaina as "Nowadays, I feel like losing all the grammar rules I have learnt". However, as a response to her corrected version of the sentence, Tunisiano added that clause and the subject and the verb. Tasnim also expressed her disagreement about Zaina's corrective feedback and provided another alternative that she viewed as correct. The learners continued negotiating the most accurate alternative through question-answer interactions that seek the groups' agreement or disagreement of the most accurate alternative form till at the end, they reached an agreement that Zaina's correction of the sentence is the most accurate linguistic form that matches the intended indication of the tense (Nowadays) in the original paragraph.

Zaina Natour: Nowadays, I "feel like losing" all the grammar rules I have learnt.

Tunisiano IB: Nowadays, I feel that I'm losing (I feel like losing) all the grammar rules I have learnt. Zaina Natour

Tasnim Saad-Aldin: oh I don't agree with Zaina Natour ......cuz she said: I feel like losing = it's better to say: I feel that I have lost.....And it's better not to use the word ' lost' at all!

Iman Bkz: Nowadays, I feel like I'm losing.....

Tasnim Saad-Aldin: it's better to say: I feel that I forgot! As a second option! I also agree with Iman Bkz AS as a third option!

Zaina Natour: great guys and thank you but Tasnim Saad-Aldin, I still think that the verb "lose" serves the idea wanted here.

Ala Sad: we can use present simple and present continuous?

Tasnim Saad-Aldin: it is right Zaina Natour, but a little bit confusing! There are better options.

Zezo Shawahin: what about nowadays dear Tasnim saad-aldin? Yes I agree with you, sweety Zaina Natour.

Tasnim Saad-Aldin: what do u mean dear Zezo Shawahin?

Zezo Shawahin: she used "Nowadays" in her revision and you skipped it so you change the tense that she uses.

Tasnim Saad-Aldin: oh I didn't skip it ...I just didn't repeat it in my comment! Dear Zezo Shawahin.

Zezo Shawahin: I meant Tasnim Saad-Aldin.

Tunisiano Ib: is it correct to say: Nowadays, I forgot (simple past) all the grammar rules i learnt.

Zezo Shawahin: so you must say Nowadays, I feel that I am forgetting.....so I think using (I am losing) it's better.... What do you think sister Tasnim Saad-Aldin?

Tasnim Saad-Aldin: oh dear Zezo Shawahin .......instead of saying: I am losing ......its better to say: I feel like losing! I feel like forgetting!

Zezo Shawahin: aha yes now you are correct sweety Tasnim Saad-Aldin.

Tasnim Saad-Aldin: hhhhhhh great Zezo Shawahin! Thanks dear! 
Zezo Shawahin: welcome sweety Tasnim Saad-Aldin.

Moreover, the analysis of their interactional exchanges in these collaborative writing revealed that the learners attended to accurate meaning. The learners' interactional exchanges in Excerpt (3) shows how they engaged in negotiating the meaning of the lexical items used by them in their revisions as a way of substituting the words or phrases in the original paragraph. The adjective (alone) in the introductory sentence of one original paragraph (Two months ago, my friend Ghadah had an embarrassing situation when she was alone at the center and was descending the stairs with her beautiful big heavy bag and her long jelbab.) was replaced by Tunisiano by another adjective (lonely) while it was not changed by Tasnim and Zaina. Moreover, after reflecting on their revisions, Tunisiano also pointed out at the use of "lonely" as a way of attending to the accurate meaning. However, Tasnim replied to Tunisiano's comment on them by emphasizing that "alone" is the correct adjective to express the intended meaning and she provided explanation distinguishing between the meanings of both adjectives. Thus, Tunisian realized her mistake in her revision of this sentence which was due to her confusion.

Tunisiano Ib: Paragraph 11: Two months ago, my friend Ghadah had an embarrassing situation when she was LONELY at the center and was descending the stairs with her beautiful big heavy bag and her long jelbab.

Tasnim Saad-Aldin: Two months ago, my friend Ghadah had an embarrassing situation when she was alone at the center and was descending the stairs with her beautiful big heavy bag and her long jelbab.

Zaina Natour: Two months ago, my friend Ghadah had an embarrassing situation when she was alone at the center and was descending the stairs with her beautiful big heavy bag and her long jelbab.

Tunisiano Ib: Thx alot honey Tasnim Saad-Aldin and Zaina Natour .i think we should use LONELY here not alone.

Tasnim Saad-Aldin: dear Tunisiano Ib : I think alone is more suitable ( as it means no one else was there except for her) because lonely can be associated more to the feeling ! I don't know but that's what I think! What can u say dear?

Tunisiano Ib: Sorry Zaina Natour and Tasnim Saad-Aldin .it sounds that I had things missed in my mind .I was really confused $\mathrm{b} / \mathrm{w}$ lonely and alone of course $u$ 're totally right .

Tasnim Saad-Aldin: that's ok dear Tunisiano Ib, thanks.

Thus, the EFL learners' involvement in peer interaction, scaffolding and negotiation strategies is consistent with the theoretical perspective of social constructivism (Cheng, 2009) especially in how the could learners construct their knowledge by interacting and scaffolding each other in a socio-cultural context. Previous researchers (e.g. Kost 2011) showed that most of strategic operations at word and phrase levels used by EFL learners tend to correct errors in mechanisms, lexis, word ending morphology and grammar. However, this is not striking as the findings of this study revealed that the EFL Arab learners also used these word and phrase-level strategies to elaborate the ideas or support the texts with further details by incorporating more information about the events, the places or time of the events in their writing, enhance the meaning by attending to accurate lexical elements and establish coherence among these small linguistic units in a sentence. As pointed out by Berbache (2007), words are the smallest semantic units in writing because they can enhance the meaning of the text if appropriately selected. Therefore, any changes on word or phrase level were found by the researcher to help the learners to better express their ideas. This can be also an important indicator of the EFL learners' fluency levels in English since strategies at word and phrase levels helped the students in the present study to play with words in a way that they in some sessions came up with two different revised versions of one original paragraph (See Appendix A). Thus, this also goes in line with the findings reported by Richardson (2006) as this researcher found that such revision strategies enabled learners to produce more writing than expected.

Concerning the online group reflection discussions as to answer the third research question, most of the responses were focused on the development of writing skill in English. Some of them pointed out at the how the group helped them to read the posts and comments and responding to such posts and comments by writing, thus, attempting to overcome a few of these problems encountered by them in writing skill and enhancing their writing. The following cluster of the participants' online responses illustrates this:

1) "Actually I have some problems in writing because of misused of joining verbs and grammar but I tried to read most of the comments written in this group to improve my skills in writing".

2) When I joined this Group I found my skills in English as a language get improve, especially in writing".

3) "Then I practiced them in comments ...Also when I write and have a mistake ... and somebody corract it for me. It stuck in my mind (the correct one)". 
The participants' responses indicated their positive perception of the group activities in enhancing their writing skill in English through active engagement and participation in the group. The students' writing skill was also developed due to their active participation in commenting writing in different topics.

4) "Yes, I think here we have interaction between two levels. The first is among and the learners themselves in writing revision exercises and the second between us and the teacher when he corrects mistakes.

5) Well first I'd like to emphasize the importance of the kind of interactions mentioned even further, and add to them the importance of Teacher-Teacher. In this group, I do believe that there is a good dynamic interaction that helps us to use English in written communication and also enhance our writing skill.

6) First, this community helps me to get a better understanding of whatever the topic or the information is about especially in writing activities posted here. It also makes me feel like I'm having an active role as an independent learner in this learning process not only a negative consumer

Based on the findings, not only did the group help the EFL learners to learn English, but also enabled them to further acquire more information and knowledge, enhance their communication skills, build new friendships, expand their social contact using English. It is evident that within time and increasing social ties among the EFL learners, they developed a sense of belonging to this CoP. This was a source of motivation for them to be active participants and it reduced their stress.

7) "This contact helped us with time to acquire information and knowledge implicitly in English" (Iman)

8) "It offers a very good chance to strengthen our social skills and in communication (Salsabela)

9) "Having the feeling of being a member in Only For English Learning as family rather than a learning group has always motivated me to participate and helped me to feel less stressed" (Zaina)

This is what has been pointed at about the popularity of FB among other SNSs among many young university students by researchers such as Boyd and Ellison (2011); Kamarul Kabilan et al., (2010); Yunus et al., (2012). According to Sun and Chang (2012), it was indicated that the social and emotional support found in the blog project was a proof of the potential of Web technologies in promoting the type of mutually beneficial social interaction that is conducive to knowledge development.

Finally, the findings in the present study reveled that despite of the usefulness of the Only For English Learning Community as an active learning environment conducive to further EFL learning practices, the EFL participants encountered several challenges varying from technical challenges as being the most dominant challenges to other less frequently encountered challenges. Thus, both the frequent electricity cut off and disconnection of the Internet or slow networking access seemed to be perceived by most of the EFL participants as the most encountered challenges, which were also found by Rubesch and McNeil (2010). In the same study by Yunus et al., (2012), the first challenged encountered by the participating students was related to the slow internet connection which was considered by them as a challenge to get connected and stay connected and to be able to participate actively in the group discussion.

10) "Challenges: time and continuous".

11) "Because of my country... Bad internet connection \& bad electricity".

The last type of challenges was related to the difficulties in understanding or following some of the daily posts especially due to time and the daily hectic or busy schedule of the participants.

12) "The challenges encountered are i can't follow all posts u give. There were a few things I didn't understand $i t$ ".

\section{Conclusion}

The central objective of this qualitative study was to investigate the opportunities and challenges of using FB group as an online CoP where EFL learners can pracrice writing in a socially situated context. The findings provided evidence of the interactive nature of this $\mathrm{CoP}$ that assisted the EFL learners to be actively involved in useful writing activities through colloberation, interaction and scaffolding or assistance in both sides; learners-learner and learner-instructor. The majority of the participants in the study expressed their positive perception of the effectiveness of this CoP in enhancing their writing through communication, socialization, sharing information and developing a sense of belonging to this CoP.

Despite the evidence of the advantages of such a FB group in enhancing the participants' EFL, the findings, based on their responses, revealed a few challenges relevant to different domains which were faced by the participants. Therefore, it can be concluded that future research should deeply investigate the potential of such 
online FB communities of learning in EFL learners' development in writing skill in English in relation to socio-cultural theories, situated theories, etc. This can be achieved by conducting a deep content analysis of the participants' comments along with observations of their different participation patterns and roles.

\section{Acknowledgements}

On behalf of my supervisor and co-supervisor, I would like to thank the UKM for its research fund and support in pursuing publishing our papers. Especial thankfulness should be dedicated to the UKM Pusat Pengurusan Siswazah for the Zamalah. Finally, I am grateful to Prof. Norizan, my main supervisor, for her persistant support.

\section{References}

Barton, D., \& Tusting, K. (2005). Beyond Communities of Practice: Language, Power and Social Contex. New York: Cambridge University Press.

Beer, D., \& Burrows, R. (2007). Sociology and, of and in Web 2.0: Some initial considerations. Sociological Research Online, 12(5). Retrieved from http://www.socresonline.org.uk/12/5/17.html

Berbache, S. (2007). Improving EFL students' writing through trained peer review (Master thesis). University of Constantine, Algeria.

Boyd, D. M., \& Ellison, N. B. (2011). Social network sites: Definition, history and scholarship. Retrieved from http://mimosa.pntic.mec.es/mvera1/textos/redessocial es.pdf [16th March 2011]

Chapelle, C. A. (1994). CALL activities: Are all they the same? System, 22, 33-45.

Chapelle, C. A. (2003). English Language Learning and Technology. Amsterdam: John Benjamins.

Cheng, G. (2009). Using game making pedagogy to facilitate student learning of interactive multimedia. Australasian Journal of Educational Technology, 25(2), 204-220. Retrieved from http://www.ascilite.org.au/ajet/ajet25/cheng.html

Cloete, S., De Villiers, C., \& Roodt, S. (2009). Facebook as an academic tool for ICT lecturers. Research presented at the annual meeting of SACLA. Eastern Cape, South Africa. Retrieved from http://www.academia.edu/849759/Facebook_as_an_academic_tool_for_ICT_lecturers

Ellis, R. (1999). Learning a second language through interaction. Amsterdam: John Benjamins.

Grandzol, C. J., \& Grandzol, J. R. (2010). Interaction in online courses: More is not always better. Online Journal of Distance Learning Administration, 13(2). Retrieved from http://www.westga.edu/ distance/ojdla/summer132/Grandzol_Grandzol132.pdf

Haverback, H. (2009). Facebook: Uncharted territory in a reading education classroom. Reading Today. Retrieved from http://www.citeulike.org/group/12747/article/6601834

Kamarul Kabilan, M., Norlida Ahmad, \& Zainol Abidin, M. J. (2010). Facebook: An online environment for learning of English in institutions of higher education? Internet and Higher Education, 13(4), 179-187. http://dx.doi.org/10.1016/j.iheduc.2010.07.003

Kern, R. G. (1995). Restructuring classroom interaction with networked computers: Effects of quantity and characteristics on language production. Modern Language Journal, 79, 457-476.

Kitade, K. (2000). L2 learners' discourse and SLA theories in CMC: Collaborative interaction in internet chat. Computer Assisted Language Learning, 13, 143-166.

Kost, C. (2011). Investigating writing strategies and revision behavior in collaborative wiki projects. CALICO Journal, 28(3), 606-620.

Lampe, C., Wohn, D. Y., Vitak, J., Ellison, N. B., \& Wash, R. (2011). Student use of Facebook for organizing collaborative classroom activities. Computer-Supported Collaborative Learning, 6, 329-347.

Lave, J., \& Wenger, E. (1991). Situated learning: Legitimate peripheral participation. Cambridge: Cambridge University Press.

Lim, Y. H. (2012). Facebook in Asia: Total Users and Age Groups. Grey Review. Retrieved April 16, 2013, from http://www.greyreview.com/2010/03/02/facebook-in-asia-totalusers-and-age-groups-latest-stats/

Liu, Y. (2010). Social media tools as a learning resource. Journal of Educational Technology Development and Exchange, 3(1), 101-114.

Long, M. H. (1996). The role of linguistic environment in second language acquisition. In C. Ritchie, T. Bhatia, \& K. Bhatia (Eds.), Handbook of second language acquisition (pp. 413-468). San Diego: Academic Press. 
Maftoon, P., \& Ghafoori, N. (2009). A comparative study of the effect of homogeneous and heterogeneous collaborative interaction on the development of EFL learners' writing skill. The Journal of Applied Linguistics, 1(2), 127-158.

Majid, A. H. A., Stapa, H. S., \& Keong, C. Y. (2012). Scaffolding through the Blended Approach: Improving the Writing Process and Performance Using Facebook. American Journal of Social Issues \& Humanities, 2(5), 336-342.

McNiff, J., \& Whitehead, J. (2006). Action Research: Principles and Practice. London: Routledge Falmer.

Moje, E. B., K. Mcintosh, K. Ciechanowski, K. Kramer, L. Ellis, R. Carillo, \& T. Collazo. (2004). Working toward third space in content area literacu: An examination of everyday funds of knowledge and discourse. Reading Research Quarterly, 39(1), 38-70.

Murad, A. S., \& Norizan, A. R. (2012). The Application of Podcasts and Vodcasts in English as Foreign Language (EFL) Listening Learning. Scottish Journal of Arts, Social Sciences and Scientific Studies, 2, 108-117.

Plastina, A. F. (2009). Nurturing communities of practice: The case of a TESOL virtual community of practice (VCoP) in Italy. TESOL in Context, 2.

Patton, M. Q. (2002). Qualitative Research and Evaluation Methods. Thousand Oaks, CA: Sage.

Bogdan, R. C., \& Biklen, S. K. (2007). Qualitative research for education: An introduction to theories and methods. Boston, USA: Pearson Education.

Brooks, S. (2010). Heterogeneous peer response groups: Engaging students in written feedback and constructive talk about writing to improve revision skills. Published Thesis for Master in Education. University of California, Davis. Retrieved from http://gradworks.umi.com/14/81/1481187.html

Richardson, W. (2006). Blogs, wikis, podcasts, and other powerful Web tools for classrooms. Thousand Oaks, CA: Corwin Press.

Roberts, W. G. (2009). Facebook interactions and writing skills of Spanish language students. Master Thesis. B. S., Lesley University.

Roblyer, M. D., McDaniel, M., Webb, M., Herman, J., \& Witty, J. V. (2010). "Findings on Facebook in higher education: A comparison of college faculty and student uses and perceptions of social networking sites". Internet and Higher Education, 13, 134-140.

Rosenblum, D. (2007). What anyone can know: The privacy risks of social networking sites. IEEE Security and Privacy, 5(3), 40-49. http://dx.doi.org/10.1109/MSP.2007.75

Rubesch, T., \& McNeil, M. (2010). Online versus face-to-face: Motivating and demotivating factors in an EAP writing course. JALT CALL Journal, 6(3), 235-250.

Schilling, J. (2006). On the pragmatics of qualitative assessment: Designing the process for content analysis. European Journal of Psychological Assessment, 22(1), 28-37.

Selwyn, N. (2007). Faceworking: Exploring students' education-related use of Facebook. Learning, Media and Technology, 34(2), 157-174.

Shih, R. C. (2011). Can Web 2.0 technology assist college students in learning English writing? Integrating Facebook and peer assessment with blended learning. Australasian Journal of Educational Technology, 27(5), 829-845.

Simon, M. (2008). Online student-teacher friendships can be tricky. Retrieved from http://articles.cnn.com/2008-08-12/tech/studentsteachers.online_1_facebook-users-myspace-social-networki ng-sites?_s=PM:TECH

Swain, M. (1985). Communicative competence. Some roles of comprehensible input and comprehensible output in its development. In S. Gass, \& C. Madden (Eds.), Input in second language acquisition (pp. 235-253). Rowley, MA: Newbury House.

Sun, Y., \& Chang, Y. (2012). Blogging to learn: Becoming EFL academic writers through collaborative dialogues. Language Learning \& Technology, 16(1), 43-61. Retrieved from http://lt.msu.edu/issues/february2012/sunchang.pdf

Tannacito, T. L. (1999). Electronic peer response groups: Case studies of computer mediated communication in a composition class. Unpublished doctoral dissertation, Indiana University. 
Vygotsky, L. (1978). Mind in Society: The Development of Higher Psychological Processes. Cambridge, MA: Harvard University Press.

Weber, R. P. (1990). Basic Content Analysis. Newbury Park, CA: Sage Publications.

White, J. (2009). The use of facebook to improve motivation and academic writing. Proceedings of the Third International Wireless Ready Symposium, 28-32.

Wenger, E. (1998). Community of Practice: Learning, meaning, and identity. U.S.A.: CUP.

Wenger, E., McDermott, R., \& Snyder, W. (2002). Cultivating communities of practice. Boston: Harvard Business School Press.

Wenger, E., \& Snyder, W. (2000). Communities of practice: The organizational frontier. Harvard Business Review, 78(1), 139-145.

Yu, H. J., \& Choe, H. (2011). The dynamics of a peer response group in a mixed-level Korean EFL writing class (pp. 187-212). Retrieved from http://english.daejin.ac.kr/ elsok/files/17_08.pdf

Yunus, M. M., Salehi, H., \& Chenzi, C. (2012). Integrating Social Networking Tools into ESL Writing Classroom: Strengths and Weaknesses. English Language Teaching, 5(8), 42-48.

\section{Appendix}

The following paragraph in its two versions (pre-corrected and post-corrected versions) was of the group assigned paragraphs on "An Embarrassing Situation in My Life" illustrates how the online group scaffolding activities assisted the participants to recognize and identify the errors, correct them through comment exchanges and corrective feedback, thus, applying grammar to writing.

(Pre-Scaffold and Feedback) One day, while i was walking on the street a man hold my hand suddenly. i shocked and tried to get rid of him. But he holds it tight. i was close to scream when he said do not worry $i$ am a blind man just help me to cross the street and i will be thankful. i felt so embarrassed and so sorry for him at the same time confused what should i do?! I helped him crossing the street and said May Allah help you.

(Post-Scaffold and Feedback 1) One day, while I was walking in/ along the street, unexpectedly/ suddenly, an unknown man held my hand. At first, I was shocked and frightened and tried to get rid of him. But he held it again tightly. Then, I was about to scream, but I felt relieved when he said, "Do not worry. I am a blind man. Just help me to cross the street, and I will be thankful to you". I felt so embarrassed and so sorry for him and at the same time, I was confused and wondering, thus, asking to myself, "What am I supposed to do?" Finally, I helped him to cross the street and said "May Allah helps you".

(Post-Scaffold and Feedback 2) One day, I woke up late for my work. So, I was terribly angry and I started to shout for minor things, and left home with a very bad mood. All of a sudden, a man held my hand with his shaking hand. At first, I was shocked and tried to get rid of him. I was also about to scream at that very moment, but felt relaxed later when I heard him saying in a soft voice: "Do not worry. I am a blind man as you can see. I want to cross the street, and I will be grateful if you help me in doing so". The poor blind man left, but I kept having a watchful eye over him to make sure everything was going smoothly with him. In the beginning, I felt sad for him, but later, I felt sorry and sad for myself. When he was thanking and praying for me, I was saying to myself "It is me who should thank $u$ for what you have taught me today through your warm beautiful smile on your face and your internal satisfaction that shines your world". Till now, I cannot forget this incident as it made me feel as if I was a newly-born person with new good morals and characters

\section{Copyrights}

Copyright for this article is retained by the author(s), with first publication rights granted to the journal.

This is an open-access article distributed under the terms and conditions of the Creative Commons Attribution license (http://creativecommons.org/licenses/by/3.0/). 